\begin{tabular}{|l|l|l|}
\hline \multicolumn{2}{|c|}{ PublisherInfo } \\
\hline \hline PublisherName & $:$ & BioMed Central \\
\hline \hline PublisherLocation & $:$ & London \\
\hline \hline PublisherImprintName & $:$ & BioMed Central \\
\hline \hline
\end{tabular}

\title{
Viral micro RNAs identified
}

\begin{tabular}{|l|c|l||}
\hline \multicolumn{2}{|c|}{ ArticleInfo } \\
\hline \hline ArticleID & $:$ & 4948 \\
\hline \hline ArticleDOI & $:$ & $10.1186 /$ gb-spotlight-20040430-01 \\
\hline \hline ArticleCitationID & $:$ & spotlight-20040430-01 \\
\hline \hline ArticleSequenceNumber & $:$ & 300 \\
\hline \hline ArticleCategory & $:$ & Research news \\
\hline ArticleFirstPage & $:$ & 1 \\
\hline \hline ArticleLastPage & $:$ & 3 \\
\hline \hline & & RegistrationDate : 2004-4-30 \\
\hline ArticleHistory & $:$ & OnlineDate \\
\hline \hline ArticleCopyright & $:$ & BioMed Central Ltd2004-4-30 \\
\hline \hline ArticleGrants & $:$ & \\
\hline \hline ArticleContext & $:$ & 130594411 \\
\hline \hline
\end{tabular}




\section{Cathy Holding}

Email: cathyholding@aol.com

A paper published in this week's Science reports for the first time the identification of micro RNAs in the Epstein-Barr virus (EBV) genome. The findings could explain previously puzzling mechanisms for infection, latency, and tumorigenesis in EBV, according to the paper's authors.

Micro RNAs are about 22 nucleotides in length and arise from defined genes to produce transcripts that typically form imperfect hairpin structures, said James C. Carrington, director of the Center for Gene Research and Biotechnology at Oregon State University. They are precisely processed to yield a single micro RNA that targets in trans one or more genes for post-transcriptional negative regulation, said Carrington, who was not involved in the study.

In spite of having been intensively studied for years, five of the 80 genes in the genome of EBV - a DNA virus - have consistently been missed, said Thomas Tuschl, from the laboratory of RNA Molecular Biology at the Rockefeller Institute and lead author on the study. "We found that the DNA virus - that shouldn't express any double-stranded RNA - had micro RNA genes. We only looked at one DNA virus, but it's probably the tip of the iceberg. I think that all the big DNA viruses use micro RNAs."

Computer predictions of the mRNA targets of the 5 micro RNAs included the tumor suppressor $\mathrm{p} 53$, retinoblastoma binding protein 3, transcription factor E2F1, and genes involved in the immune response, such as a BCL8 homolog and the ICOS ligand precursor, a gene expressed in B cells that activates the immune system, according to Tuschl.

The findings could also explain why EBV is linked to cancers such as Burkitt and Hodgkin lymphomas. "It is also possible that some of the [computer-predicted] targets appear to be modulators of growth control, and so, in part, the micro RNA is explaining how these growth dysregulations are taking place," Tuschl said.

Micro RNAs are known to be a highly conserved mechanism of regulation in animals and plants, according to Sarah C. Hake, director of the US Department of Agriculture Plant Gene Expression Center, Albany, Calif. "Plants that are 400 million years apart have the same micro RNA sequences," said Hake, who was not involved in the study. "They're not coding any protein, so the selection is really acting at the nucleotide level. People have found conserved micro RNA sequences in animals and humans and plants - and now they're also in viruses, so it's like in all life - maybe viruses are life too."

Micro RNAs are expressed quite well in latent infected cells, according to Carrington. Most EBV genes are not expressed in latent cells - one of the reasons that the virus becomes latent - with the exception of a few latent-associated transcripts. "What's even more interesting is that one of the micro RNAs, miR-BART2, has the potential to target one of the EBV genes that encodes a DNA polymerase," said Carrington.

"Degradation of that transcript could conceivably contribute to either the establishment or maintenance of latency," said Carrington.

Tuschl said that while computer-predicted targets for the micro RNAs lack experimental validation, they are likely to be correct because they are logical. "When you look at the frequency at what you hit, 
there is an unusual representation of B-cell- specific targets - which is the preferred host cell of the EBV. If you look at them in more detail, you find that if you repress some of these genes, that would help the virus escape detection by the immune system."

"There are very exciting possibilities that these micro RNAs could be important in persistent latent infection," said David Thorley-Lawson, professor of pathology at Tufts University School of Medicine. "They could be important in tumorigenesis, particularly Burkitts lymphoma, where we really don't have any good clues about what EBV is doing, but right now that's all speculation, because we don't have the information."

\section{References}

1. Science, [http://www.sciencemag.org/]

2. Epstein-Barr Virus and Infectious Mononucleosis, [http://www.cdc.gov/ncidod/diseases/ebv.htm]

3. James C. Carrington, [http://www.science.oregonstate.edu/mfbsc/people/carrington.htm]

4. Thomas Tuschl, [http://www.rockefeller.edu/labheads/tuschl/]

5. Sarah C. Hake, [http://plantbio.berkeley.edu/faculty/faculty_pages/Hake.html]

6. David Thorley-Lawson, [http://www.tufts.edu/sackler/immunology/thorley-lawson/intro.html] 